\title{
The practice of capital structure choice in the Czech Republic: A comparative study based on the global data
}

\author{
Lenka Strýčková \\ Technical University of Liberec, \\ Liberec, Crech Republic \\ Email:lenka.stryckova@tul.č.
}

\begin{abstract}
The aim of this contribution is to reveal the general practice in corporate financing in the Czech Republic, capital structure choice in particular, by means of comparison with the global data. The comparative study is based on primary data from the Czech Republic obtained via a questionnaire survey, and comparison with the data from various countries in Europe and America published in empirical surveys since 2001. The crux of this comparison is the use of the same questions that were used by Graham and Harvey for the first time in 2001. Unlike the original study, which examined several aspects of corporate finance in a single country, this study is focused on the cross-country comparisons of views on determinants of capital structure. The study revealed both differences and similarities between Czech, American and European companies. As the most important factor affecting the choice of the appropriate amount of debt for Czech respondents was "Financial flexibility", likewise in the other countries. Surprisingly, the tax advantages are not considered to be of a high importance to Czech firms and a striking proportion of respondents have no target debt ratio; such results weren't found by any previous study.
\end{abstract}

Keywords: capital structure, corporate finance, cross-country comparison, debt, equity.

\section{JEL Classification: G32}

\section{INTRODUCTION}

This paper deals with the capital structure of companies in the Czech Republic. The aim of the study is to investigate the corporate financing practice of Czech companies and to compare it with the global data. In order to achieve this goal, the study compares the data from survey conducted in the CR to survey data from various countries from Europe and America published since 2001. The essence of this comparison is the use of the same questions that were used by Graham and Harvey for the first time in 2001 in so called the Duke Special Survey on Corporate Financial Policy. Since that time the same questionnaire form has been used in several other investigations all over the world. So far, no study has been published based on 
the data from the Czech Republic, at least to the extent of author's knowledge. The main benefit of this paper is a fulfilment of this gap. Unlike the study of Graham and Harvey, which examined several aspects of corporate finance in a single country, this study is focused on cross-country comparisons of managerial views on determinants of capital structure.

Long-term financing in the Czech Republic is based on the continental system of corporate financing, characterized by a predominance of debt financing instead of equity financing. The Czech Republic as a transitive country still differs in many ways from the traditional market-oriented European countries. There are generally two groups of capital structure theories. The static theories search for the optimal debt-toequity ratio, whereas the dynamic theories declare that there is no defined target capital structure; they are primarily based on the assumption that each firm continually optimizes its financial decisions according to the changing specific conditions. All leading theories of financing assume that firms have access to reasonably well-functioning capital markets and to modern financial institutions. This assumption is not always true. Most capital structure theory was developed for U.S. public corporations, and even in that wellstructured setting, no general theory emerges (Myers, 2003).

Several studies have already examined whether European and U.S. managers' views on capital structure are driven by similar factors. The original questionnaire was prepared by Graham and Harvey (2001), followed by a wave of other surveys based on the same survey questions, e.g. Bancel and Mittoo (2004), Brounen et al. (2006), Benetti et al. (2007), that aimed at narrowing the gap between academics and practitioners. The cross-country comparison of the Czech and the global data is of particular importance given the fact that the practice of corporate financing in transitive economies and emerging markets has been considerably ignored in the finance literature so far. Such economies feature less liquid capital markets, volatile economic conditions and political situations, imperfect legislation, and large amounts of information asymmetry. Novelty of this study is the search for the empirical data for Graham and Harvey's survey (some parts) in one the Central and Eastern European countries - the Czech Republic.

The structure of the paper proceeds as follows. In section 1, theoretical background to basic capital structure theories will be mentioned, followed by introduction of default empirical study of Graham and Harvey conducted in 2001. In section 2, the methodology will be explained first, the data and empirical results will be explained next. The paper will conclude in the last section.

The results of this paper should significantly contribute to the literature by examining the practice of corporate finance in the Czech Republic.

\section{THEORETICAL BACKGROUND}

Corporate long-term capital structure and its optimization are continuously discussed by both academics and financial managers. Despite fundamental theoretical developments in recent years, the general understanding of corporate capital structure remains incomplete. A proportionate mix of debt and equity in corporate financing has been the subject of intensive theoretical modelling and empirical examination over the years.

One of the first theories of capital structure was the famous theory of Modigliani and Miller (1958). This theory holds that a firm's capital structure does not affect its value if markets have perfect information and there are no taxes or bankruptcy costs. The theory was later extended to include the effects of taxation (in 1963), by justifying the preference of debt capital in order to take advantage of the tax shield effect.

Static trade-off models come from MM proposition. They point out that companies will favour debt as a source of financing when they enjoy a tax shield. Trade-off theory assumes that each firm has a valuemaximizing optimal capital structure that minimizes its overall weighted average cost of capital (WACC). 
As the after-tax cost of debt is usually less expensive than equity, companies will add debt up to the point where the risk of bankruptcy raises to the WACC.

The pecking order theory was set out in Myers and Majluf (1984). It is based on informational asymmetry and suggests that firms do not have leverage targets. They use debt only when retained earnings are insufficient and raise external equity capital only as a last resort. In the pure version of the pecking order theory, external equity is never issued - because of the negative signal sent by this decision to investors. Brealey and Myers (1996) indicate that the most important source of corporate financing is private equity consisting of owners deposits and retained earnings. According to them, an additional source of financing of great importance is debt.

The studies of Shyam-Sunder and Myers (1999), and Fama, and French suggest a model that embeds both fundamental theories of capital structure: the trade-off and the pecking order theory. The conclusion which emerges is that the two theories each contribute significantly to the explanation of observed debt levels.

In general, capital structure is said to be optimum when the marginal real cost (explicit as well as implicit) of each available source of financing is identical. With an optimum debt and equity mix, the cost of capital is minimal and the total value of the firm is maximal (Khan and Jain, 2007).

Since the introduction of the main theories of capital structure, recent developments in this field have focused more on empirical and econometric testing of these theories.

The most famous empirical study is by Graham and Harvey (2001). In their study, the authors analyse the practice of corporate finance within a sample of 392 CFOs from the U.S.A., by focusing on the relevance of important theoretical factors in capital structure choice, as well as in cost of capital estimations and capital budgeting. The survey focused on three areas: capital budgeting, cost of capital, and capital structure. The authors found moderate evidence that firms follow the trade-off theory and target their debt ratios. They also found some support for the pecking-order theory. Their results showed that firms value financial flexibility, but its importance is not related to information asymmetry or growth options in the manner predicted by the pecking-order theory. They found little evidence that other factors - including agency costs, signalling, asset substitution, free cash flow and product market concerns - affected capital structure choice. They also reported that managers used many informal criteria, such as credit rating and earnings per share dilution, in making their financing decisions. Graham and Harvey created a questionnaire that was later used by other authors in the same form for cross-country comparison of the results.

A subsequent study was performed by Bancel and Mittoo (2004). They examined capital structure policies of 87 CFOs from 16 different European countries. Due to the limited sample size, these authors did not present country-specific results, and whereas Graham and Harvey surveyed both publicly listed and private firms, Bancel and Mittoo's sample exclusively consisted of public firms. Their conclusions are as follows.

First, European managers use factors similar to those used by their U.S. peers for their financing decisions. However, there are differences across countries in several dimensions, especially between Scandinavian and non-Scandinavian countries. Second, the quality of the country's legal system explains cross-country variations in the rankings of several major factors, but so do other country-specific factors such as cost of capital. In addition, although differences in debt policy factors vary systematically with the quality of a country's legal system, firm-specific factors such as the firm's growth opportunities strongly influence the common stock policy factors. Overall, their results supported the view that most firms determine their optimal capital structure by trading off factors such as the tax advantage of debt, bankruptcy costs, agency costs, and accessibility to external financing. 
Brounen, de Jong and Koedijk (2006) in their survey also used the same questions as Graham and Harvey. In addition, they posed questions about cost of capital estimations and capital budgeting; the results for these questions are described in Brounen et al. (2004). Their survey (2005) presented results for a sample of 313 CFOs from four European countries: the United Kingdom, the Netherlands, Germany, and France. They concluded that the static trade-off theory received moderate confirmation. According to their conclusions, financial flexibility was important, but not driven by the pecking-order theory. Several practical considerations were highly relevant. Contrary to the institutional variations, they documented strong resemblances among the four European countries and also with the U.S. when comparing capital structure policies. Their findings were also surprising in comparison with the results of Bancel and Mittoo, who found signalling and agency problems to be important factors in capital structure choice.

Benetti, Decourt and Terra (2007) performed a comparison of 160 respondent Brazilian firms with the sample gathered by Graham and Harvey. They documented several contrasts in financial policies between countries in developed and emerging markets. They explain the contrasts by differences in the economic environment, such as the role of the legal, institutional, and macroeconomic frameworks.

Even some other empirical studies used the afore-mentioned questionnaire of Graham and Harvey; let's name, for example, Archbold and Laziridis (2010). Those authors used only reduced number of questions from Graham and Harvey's questionnaire to investigate and compare the situation in Greece and the United Kingdom. Kohli and Sharma (2015) attempted to capture the similarities and differences in corporate financial behavior of Indian MNCs using also the Duke Special Survey on Corporate Financial Policy, how the original Graham and Harvey's questionnaire is often called.

\section{COMPARATIVE STUDY OF CORPORATE FINANCING IN THE CZECH REPUBLIC}

\subsection{Research methodology}

For the preparing of this study, the method of analysis of expert publications and scientific papers was used first. On this basis, the theoretical background was elaborated by means of the synthesis of the obtained knowledge. The study also includes the results of an empirical investigation and a comparative study.

This comparative study (as well as all cited studies) is based on the comparison of global data obtained via questionnaire that was created by Graham and Harvey (2001), referred to as the Duke Special Survey on Corporate Policy (hereinafter G\&H 2001), which has been used several times since then in various countries of America and Europe for cross-country comparison. The first step involved obtaining permission from the questionnaire's authors. The authorisation was granted by Professor Graham. The second step was to get permission from the authors of those surveys with which the results of this study are compared. The usage of the data and findings from 16 European countries (2004) was kindly authorised by Professor Bancel; permission to use Brazilian data was granted by Professor Benetti.

For cross-country comparison, European data from the survey of Bancel and Mittoo (hereinafter B\&M 2004), data from the United Kingdom, the Netherlands, Germany, and France obtained in the survey by Brounen, de Jong and Koedijk (hereinafter Brounen et al. 2006), and Brazilian data gathered by Benetti, Decourt and Terra (hereinafter Benetti et al. 2007) were used. It is necessary to admit here that the crosscountry comparison cannot be entirely accurate due to differences in accounting and disclosure practices for financial data across countries.

The empirical investigation was conducted in several phases. The first phase involved determination of the population and the representative sample. The database of companies and institutions MagnusWeb 
which contains an overview of all registered business entities in the Czech Republic was used as the source of data on the subjects. All economically active business companies in the Czech Republic served as the population of investigation; the sample consisted of 2000 randomly selected companies (using a random number generator).

The next phase included the formation and distribution of the questionnaire. The questionnaire used in this study was distributed by students of the Faculty of Economics to CFOs of companies across the Czech Republic. Via personal interviews and electronically students managed to get 220 (as of only 197 properly completed) questionnaires. The overall response rate was $9.9 \%$ (G\&H had $9 \%$ response rate, B\&M $12 \%$, Brounen et al. 5\%, Benetti et al. $9.4 \%$ ). Overall, the sample can be considered as representative of the overall universe of firms. Number of respondents can be regarded as a set of a great magnitude, and therefore is suitable for statistical evaluation.

The questionnaire contained 48 questions focused on the evaluation of corporate performance from the accounting and financial point of view. In order to provide the opportunity to compare results, it also contained four questions focused on corporate debt strategy translated into Czech from the Duke Special Survey on Corporate Policy (questions 11 to 14 in particular; question 12 had 15 subparts, question 13 had 9 subparts). The data evaluation was carried out using methods of descriptive statistics.

The questionnaire also contained demographic information about the sample firms. With respect to the fundamental structure of the Czech companies and the number of publicly traded companies on the capital market, the sample contained primarily non-publicly traded companies, with all legal forms of business, from all business sectors. The Czech companies are smaller and less internationalized in comparison to the U.S. firms, so the firms were categorized according to sales revenues as in the original questionnaire (1=<25 mil EUR, 2=25-99 mil EUR, 3=100-499 mil EUR, 4=500-999 mil EUR, 5=1-5 bill, $6=>5$ bill EUR, 9=missing) as well as the number of employees (according to the Czech standards: 0-9 employees (micro-sized enterprise), 10-49 employees (small-sized enterprise), 50-249 employees (mediumsized enterprise), 250 and more employees (large-sized enterprise)). Details of the respondent samples are provided in Table 1.

A limited liability company is statistically the most frequently significant legal form of business in the Czech sample, which corresponds with the population. Statistically, the most frequently significant business sectors in the sample were Manufacturing and Retail and Wholesale. With respect to the total number of employees, there is no statistically significant difference in the frequency of respondent enterprises according to company size. The companies range from very small (micro-sized enterprises) to very large (large-sized enterprises). The distribution of respondents according to company size, measured in conformity with world standards by sales revenue in millions of euros, confirms the presence of relatively small companies operating in the Czech Republic. Statistically, the most frequently significant company size in the sample was with sales revenues of under 25 million EUR. The distribution of respondents according to ownership in table 1 confirms the low internationalization of the Czech firms. Statistically, the most frequently significant ownership in the sample was ownership by domestic (Czech) capital.

Data was processed by descriptive statistics containing the percentage of scores and mean values. Table 1 also presents a summary of information about the respondent firms in the selected survey samples (Graham and Harvey (2001), Bancel and Mittoo (2004), Brounen et al. (2006), Benetti (2007)). Regarding the firms' size distribution in the samples, the U.K. and France have relatively more firms in the smallest size group, like the Czech sample. This is noticeably different from the European data of Bancel and Mittoo, of whose observations more than $80 \%$ belong to the group with sales over $€ 1$ billion. The distinct sample differences are direct results of the underlying sample selection procedures of particular surveys. The distribution across industry types is quite similar in all countries, with most firms belonging to manufacturing 
in each sample. The only exception is the sample of Bancel and Mittoo, in which the majority of respondents belong to the financial and technological industries, followed by mining and construction.

The cross-country comparison of mean rating of responses to given question is based on the Pearson Correlation. The coefficient was computed for the whole data set. This is supposed to reveal whether there are any similarities in responses between selected countries.

\subsection{Empirical results}

This section presents and discusses the main findings of the survey conducted in the Czech Republic, and compares them to those reported in the above-mentioned previous studies. The survey was focused on separate questions about debt and equity, target and actual debt ratios, and factors that affect the appropriate amount of debt and the firm's debt policy.

\subsubsection{Target debt ratios}

One of the longest-standing unresolved questions about capital structure is whether firms have target debt ratios. This basic question still remains unanswered despite a lot of extensive research.

One of the questions was whether firms have an optimal or "target" debt-equity ratio. Figure 1 shows the distribution of answers to the question "Does your firm have a target range for your debt ratio?". An astonishing $73.85 \%$ of respondents in the Czech Republic have no target debt ratio. Another $12.82 \%$ of respondents have a flexible target, and $5.64 \%$ have a somewhat tight target or range. Only the remaining $7.69 \%$ have a very strict target debt ratio. These results provide support for the notion that firms don't have leverage targets, in accordance with the pecking order theory based on information asymmetry. Under this theory firms use debt only when retained earnings are insufficient, and raise external equity capital only as a last resort.

The results of Graham and Harvey (Fig. 1) provided mixed support for the notion that companies trade off costs and benefits to derive an optimal debt ratio. In terms of target debt ratios, the U.S. firms set stricter targets than their counterparts in Brazil, where more than $68 \%$ of the firms claim to have no or loose target ratios. According to Bancel and Mittoo, about $75 \%$ of the European firms have a target debtto-equity ratio (this survey didn't use the same four-level scale as the other surveys).

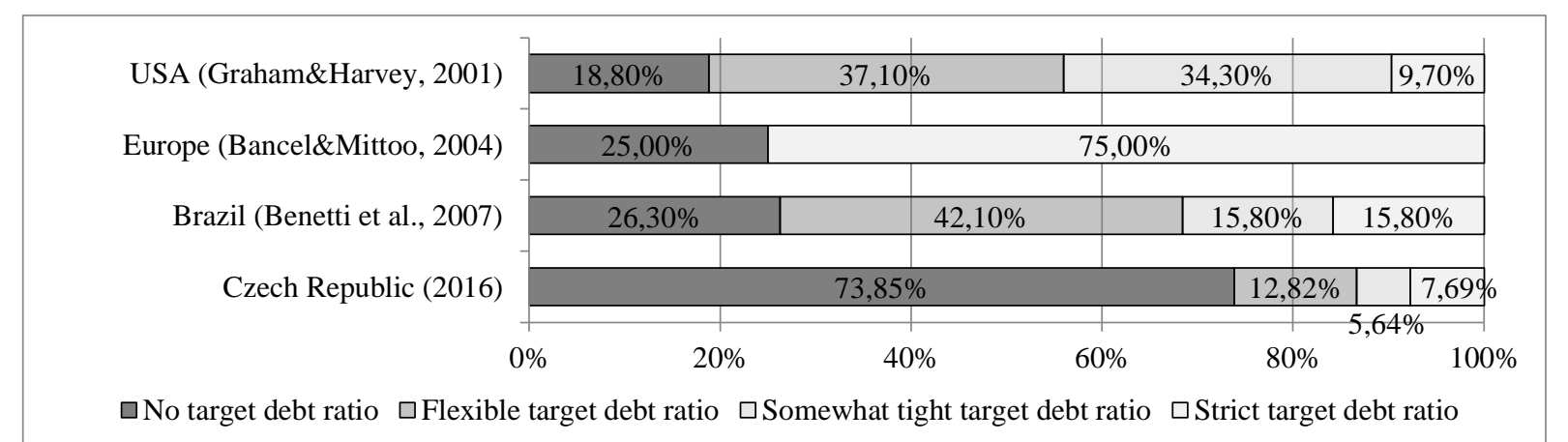

Figure 1. Cross-country comparison: Survey responses to the question: "Does your firm have a target range for your debt ratio?"

Source: Graham and Harvey (2001), Bancel and Mittoo (2004), Benetti (2007), own elaboration 
The authors of the European survey (Brounen et al., 2006, not included in Fig. 1) report that in the U.K., the Netherlands and Germany over two-thirds of firms aim for some target debt ratio. Of the French firms in the sample, less than a third have a target ratio (and more than half have no target debt ratio). A second striking result was that in each of the countries merely $10 \%$ of all firms maintain a strict target. They also concluded that although the target ratio is evidence in favour of the static trade-off theory, the theory also prescribes specific determinants of this target debt ratio.

\subsubsection{Actual debt ratios}

The data for levels of actual debt ratios are based on the question, "What is your firm's approximate long-term debt/total assets ratio?".

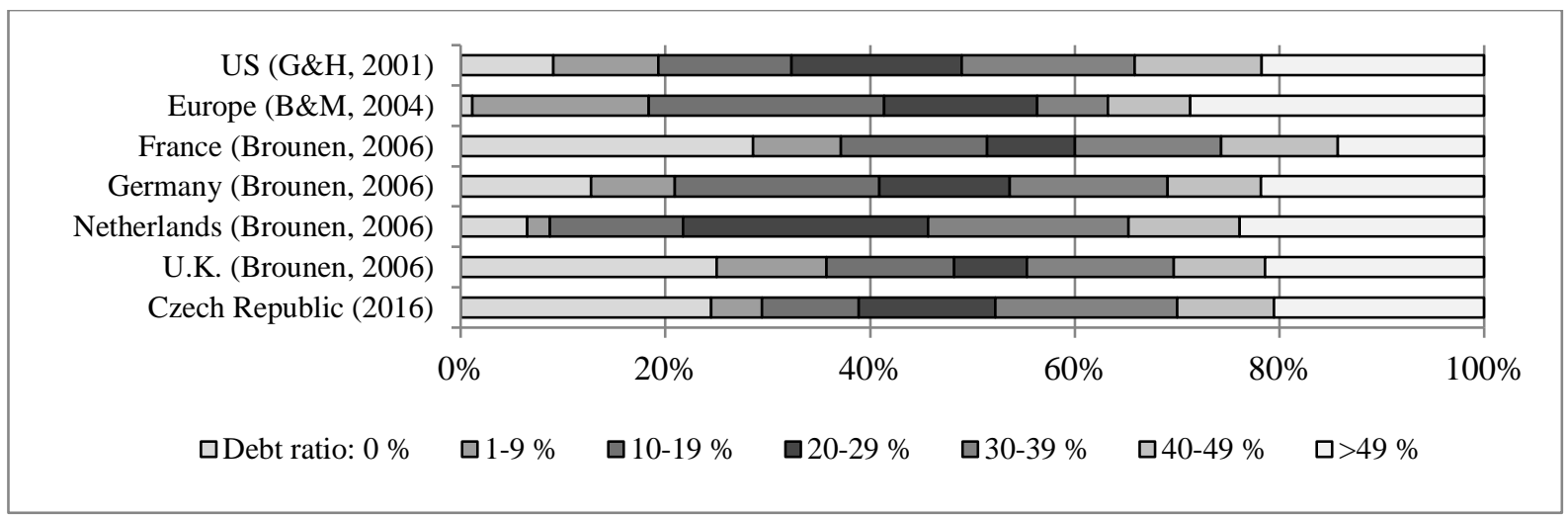

Figure 2. Cross-country comparison: Survey responses to the question: "What is your firm's approximate long-term debt/total assets ratio?"

Source: Graham and Harvey (2001), Bancel and Mittoo (2004), Brounen et al. (2006), Benetti (2007), own elaboration

The distribution of debt levels are specified in the middle section of Table 1 and illustrated in Figure 2. The distribution of debt levels in the U.S. is fairly uniform. Approximately one-third of the sample firms have debt-to-asset ratios below $20 \%$, another third have debt ratios between $20 \%$ and $40 \%$, and the remaining firms have debt ratios greater than $40 \%$. The average long-term debt ratio of European firms according to $\mathrm{B} \& \mathrm{M}$ is $66 \%$, but it varies from a minimum of $4 \%$ to a maximum of $96 \%$. The average (median) debt ratio is $113 \%(35 \%)$ and the average (median) long-term debt ratio is $44 \%(24 \%)$. In comparison to other samples, the study of European firms reveals the largest proportion of respondents with a long-term debt ratio higher than $50 \%$, and at the same time the smallest proportion of respondents with a long-term debt ratio of $0 \%$. Firms from France, the U. K. and the Czech Republic rank among samples with the highest proportion of respondents with a long-term debt ratio of $0 \%$ (proportions are between $24 \%$ and $29 \%$ ). The proportion of firms from the Czech Republic with a long-term debt ratio higher than $50 \%$ is comparable to most countries (proportions are between $20 \%$ and $29 \%$ ) except France (just $14 \%$ ). 
Table 1

Cross-country comparison: sample statistics (distribution of respondents in percentage)

\begin{tabular}{|c|c|c|c|c|c|c|c|c|c|}
\hline & & \multirow[b]{2}{*}{$\begin{array}{c}\text { U.S. } \\
\text { (G\&H, } \\
\text { 2001) }\end{array}$} & \multirow[b]{2}{*}{$\begin{array}{c}\text { Europe } \\
\text { (B\&M } \\
\text { 2004) }\end{array}$} & \multicolumn{4}{|c|}{ Europe (Brounen et al., 2006) } & \multirow[b]{2}{*}{$\begin{array}{c}\text { Brazil } \\
\text { (Benetti } \\
\text { et al. } \\
\text { 2007) }\end{array}$} & \multirow[b]{2}{*}{$\begin{array}{c}\text { Czech } \\
\text { Rep } \\
(2016)\end{array}$} \\
\hline & & & & U.K. & $\begin{array}{c}\text { Netherl } \\
\text { ands }\end{array}$ & $\begin{array}{c}\text { Germa } \\
\text { ny }\end{array}$ & France & & \\
\hline Number of firms & & 392 & 87 & 68 & 52 & 132 & 61 & 160 & 197 \\
\hline \multirow{6}{*}{$\begin{array}{l}\text { Sales revenue in } \\
\text { EUR (company } \\
\text { size) }\end{array}$} & $<€ 25$ million & 7.91 & 0.00 & 29.41 & 7.84 & 8.40 & 30.51 & 26.80 & 76.60 \\
\hline & $€ 25-€ 99$ million & 16.84 & 1.15 & 32.29 & 39.22 & 34.35 & 32.20 & 6.90 & 15.70 \\
\hline & $€ 100-€ 499$ million & 22.19 & 9.20 & 16.18 & 25.49 & 38.17 & 16.95 & 31.00 & 3.60 \\
\hline & $€ 500-€ 999$ million & 8.42 & 8.05 & 4.41 & 7.84 & 6.87 & 5.08 & 23.90 & 1.50 \\
\hline & $\begin{array}{l}€ 1000-€ 4999 \\
\text { million }\end{array}$ & 22.70 & 41.38 & 8.82 & 9.80 & 9.92 & 5.08 & 1.40 & 2.00 \\
\hline & $>€ 4999$ million & 18.37 & 40.23 & 5.88 & 9.80 & 2.29 & 10.17 & 0.00 & 0.50 \\
\hline \multirow[t]{7}{*}{$\begin{array}{l}\text { Industry/Business } \\
\text { sector }\end{array}$} & $\begin{array}{l}\text { Retail and } \\
\text { Wholesale } \\
\end{array}$ & 9.95 & 6.90 & 19.05 & 12.00 & 6.45 & 24.14 & 13.20 & 28.93 \\
\hline & $\begin{array}{l}\text { Mining, } \\
\text { Construction }\end{array}$ & 3.57 & 16.09 & 4.76 & 2.00 & 9.68 & 18.97 & 5.90 & 8.12 \\
\hline & Manufacturing & 37.50 & 13.79 & 41.27 & 38.00 & 50.00 & 31.01 & 38.20 & 33.50 \\
\hline & $\begin{array}{l}\text { Transport / } \\
\text { Energy }\end{array}$ & 11.22 & 8.05 & 6.35 & 16.00 & 15.32 & 5.17 & 16.20 & 7.61 \\
\hline & $\begin{array}{l}\text { Communication / } \\
\text { Media }\end{array}$ & 5.10 & 8.05 & 4.76 & 18.00 & 4.84 & 5.17 & 5.90 & 6.60 \\
\hline & $\begin{array}{l}\text { Bank / Finance / } \\
\text { Insurance }\end{array}$ & 13.78 & 18.39 & 9.52 & 10.00 & 2.42 & 3.45 & 13.20 & 4.57 \\
\hline & $\begin{array}{l}\text { Tech (software / } \\
\text { biotech / etc.) }\end{array}$ & 8.42 & 18.39 & 14.29 & 4.00 & 11.29 & 12.07 & 7.40 & 10.66 \\
\hline \multirow{7}{*}{$\begin{array}{l}\text { Long-term debt } \\
\text { ratio }\end{array}$} & $0 \%$ & 9.06 & 1.15 & 25.00 & 6.52 & 12.73 & 28.57 & n.a. & 24.44 \\
\hline & $1-9 \%$ & 10.27 & 17.24 & 10.71 & 2.17 & 8.18 & 8.57 & n.a. & 5.00 \\
\hline & $10-19 \%$ & 12.99 & 22.99 & 12.50 & 13.04 & 20.00 & 14.29 & n.a. & 9.44 \\
\hline & $20-29 \%$ & 16.62 & 14.94 & 7.14 & 23.91 & 12.73 & 8.57 & n.a. & 13.33 \\
\hline & $30-39 \%$ & 16.92 & 6.90 & 14.29 & 19.57 & 15.45 & 14.29 & n.a. & 17.78 \\
\hline & $40-49 \%$ & 12.39 & 8.05 & 8.93 & 10.87 & 9.09 & 11.43 & n.a. & 9.44 \\
\hline & $>49 \%$ & 21.75 & 28.74 & 21.43 & 23.91 & 21.82 & 14.29 & n.a. & 20.56 \\
\hline \multicolumn{10}{|c|}{ Demographic specification of the Czech sample } \\
\hline \multirow{4}{*}{$\begin{array}{l}\text { Number of } \\
\text { employees } \\
\text { (company size) }\end{array}$} & \multicolumn{2}{|c|}{$\begin{array}{l}\text { 0-9 employees (micro-sized } \\
\text { enterprise) }\end{array}$} & - & - & - & - & - & - & 30.5 \\
\hline & \multicolumn{2}{|c|}{$\begin{array}{l}\text { 10-49 employees (small-sized } \\
\text { enterprise) }\end{array}$} & - & - & - & - & - & - & 25.4 \\
\hline & \multicolumn{2}{|c|}{$\begin{array}{l}50-249 \text { employees (medium- } \\
\text { sized enterprise) }\end{array}$} & - & - & - & - & - & - & 22.3 \\
\hline & \multicolumn{2}{|c|}{$\begin{array}{l}250 \text { and more employees } \\
\text { (large-sized enterprise) }\end{array}$} & - & - & - & - & - & - & 21.8 \\
\hline \multirow{3}{*}{$\begin{array}{l}\text { Legal form of } \\
\text { business }\end{array}$} & Joint-sto & & - & - & - & - & - & - & 21.8 \\
\hline & Limited 1 & pany & - & - & - & - & - & - & 58.4 \\
\hline & Other & & - & - & - & - & - & - & 19.8 \\
\hline Ownership & Domesti & & - & - & - & - & - & - & 73.6 \\
\hline & Foreign & & - & - & - & - & - & - & 26.4 \\
\hline
\end{tabular}

Source: Graham and Harvey (2001), Bancel and Mittoo (2004), Brounen et al. (2006), Benetti (2007), own elaboration $(2016$ 


\subsubsection{Factors affecting the appropriate amount of debt - Analysis of the Czech sample}

To determine the factors affecting the choice of the appropriate amount of debt as well as other factors affecting the firm's debt policy, the Likert scale was used ( 0 meaning not important, 4 meaning very important). The Likert Scale technique (frequently known as the agree-disagree scale) presents respondents with a series of attitude statements, for each of which they are asked whether, and how strongly, they agree or disagree, using one of a number of positions on a five-point scale (Brace, 2013).

The questionnaire contained two fundamental capital structure questions, each with several subparts concerning particular factors: "What factors affect how you choose the appropriate amount of debt for your firm?" (Table 2) and "What other factors affect your firm's debt policy?" (Table 3). Tables 2 and 3 illustrate the distribution of answers to the questionnaire survey conducted in the Czech Republic.

Table 2

Analysis of the Czech sample: Survey responses to the question: "What factors affect how you choose the appropriate amount of debt for your firm?"

\begin{tabular}{|c|c|c|c|c|c|c|c|c|c|c|c|c|c|}
\hline & & \multicolumn{2}{|c|}{ Sample } & \multicolumn{2}{|c|}{ Size } & \multicolumn{3}{|c|}{ Business sector } & \multicolumn{3}{|c|}{ Legal form } & \multicolumn{2}{|c|}{$\begin{array}{l}\text { Target debt } \\
\text { ratio }\end{array}$} \\
\hline & & $\%$ & Mean & SME & Large & Manuf. & $\begin{array}{l}\text { Retail } \\
\text { /Wh. }\end{array}$ & Others & JSC & LLC & Others & Yes & No \\
\hline a) & The tax advantage of interest deductibility & 7.14 & 0.73 & 0.72 & 0.78 & 0.81 & 0.85 & 0.58 & 0.84 & 0.75 & 0.57 & 1.00 & 0.63 \\
\hline b) & $\begin{array}{l}\text { The potential costs of bankruptcy, near-bankruptcy, or } \\
\text { financial distress }\end{array}$ & 8.43 & 0.66 & 0.68 & 0.59 & 0.55 & 1.04 & 0.48 & 0.76 & 0.70 & 0.43 & 1.05 & 0.52 \\
\hline c) & The debt levels of other firms in our industry & 10.78 & 0.77 & 0.76 & 0.84 & 0.89 & 0.74 & 0.69 & 0.92 & 0.83 & 0.40 & 0.41 & 0.71 \\
\hline d) & Our credit rating (as assigned by rating agencies) & 18.07 & 1.19 & 1.18 & 1.22 & 1.26 & 1.40 & 0.95 & 1.57 & 1.26 & 0.47 & 2.45 & 0.88 \\
\hline e) & The transactions costs and fees for issuing debt & 21.56 & 1.33 & 1.28 & 1.53 & 1.42 & 1.47 & 1.16 & 1.68 & 1.33 & 0.93 & 2.23 & 1.11 \\
\hline f) & $\begin{array}{l}\text { The personal tax cost our investors face when they receive } \\
\text { interest income }\end{array}$ & 8.38 & 0.56 & 0.49 & 0.81 & 0.54 & 0.62 & 0.53 & 0.81 & 0.56 & 0.23 & 1.14 & 0.41 \\
\hline g) & $\begin{array}{l}\text { Financial flexibility (we restrict debt so we have enough } \\
\text { internal funds available to pursue new projects when they } \\
\text { come along) }\end{array}$ & 33.53 & 1.71 & 1.77 & 1.47 & 1.67 & 1.74 & 1.72 & 1.86 & 1.73 & 1.43 & 1.90 & 1.72 \\
\hline h) & The volatility of our earnings and cash flows & 23.81 & 1.36 & 1.42 & 1.14 & 1.39 & 1.35 & 1.33 & 1.81 & 1.35 & 0.80 & 1.73 & 1.20 \\
\hline i) & $\begin{array}{l}\text { We limit debt so our customers/suppliers are not worried } \\
\text { about our firm going out of business }\end{array}$ & 18.67 & 1.24 & 1.34 & 0.89 & 1.30 & 1.36 & 1.10 & 1.00 & 1.48 & 0.72 & 1.41 & 1.15 \\
\hline i) & $\begin{array}{l}\text { We try to have enough debt that we are not an attractive } \\
\text { takeover target }\end{array}$ & 3.57 & 0.38 & 0.42 & 0.24 & 0.46 & 0.49 & 0.23 & 0.54 & 0.40 & 0.13 & 0.41 & 0.36 \\
\hline k) & $\begin{array}{l}\text { If we issue debt our competitors know that we are very } \\
\text { unlikely to reduce our output }\end{array}$ & 5.39 & 0.55 & 0.58 & 0.43 & 0.58 & 0.64 & 0.45 & 0.78 & 0.54 & 0.27 & 0.91 & 0.47 \\
\hline 1) & $\begin{array}{l}\text { A high debt ratio helps us bargain for concessions from } \\
\text { our employees }\end{array}$ & 4.19 & 0.46 & 0.47 & 0.41 & 0.39 & 0.68 & 0.36 & 0.57 & 0.51 & 0.13 & 0.55 & 0.41 \\
\hline $\mathrm{m})$ & $\begin{array}{l}\text { To ensure that upper management works hard and } \\
\text { efficiently, we issue sufficient debt to make sure that a } \\
\text { large portion of our cash flow is committed to interest } \\
\text { payments }\end{array}$ & 1.22 & 0.36 & 0.34 & 0.43 & 0.24 & 0.57 & 0.31 & 0.51 & 0.32 & 0.30 & 0.59 & 0.28 \\
\hline n) & $\begin{array}{l}\text { We restrict our borrowing so that profits from new/future } \\
\text { projects can be captured fully by shareholders and do not } \\
\text { have to be paid out as interest to debtholders }\end{array}$ & 3.64 & 1.44 & 1.46 & 1.38 & 1.65 & 1.46 & 1.25 & 1.59 & 1.56 & 0.87 & 1.71 & 1.33 \\
\hline
\end{tabular}

Note: $\%$ - is the percentage of scores 3 -important and 4 - very important. Mean is the average score for each question. Responses in Likert Scale 0 - 4. Size: SME-less than 250 employees, Large-more than 
250 employees. Legal form: JSC-joint stock company, LLC-limited liability company, Others-other legal forms. Target debt ratio: Yes-answers: strict target ratio+somewhat tight target range, No-no target.

Source: own investigation

Financial flexibility proved to be the most important factor affecting the choice of the appropriate amount of debt for the sample firms (with an overall rating of 1.71 in Table 2), while it was slightly more important for small and medium-sized enterprises, from the retail and wholesale business sector, with the legal form of a joint-stock company, and for companies which have a target debt ratio. The second most important factor was seen to be the volatility of a firm's earnings and cash flows (rating 1.36). This factor was more important for SME, firms from manufacturing industries, firms with the legal form of a JSC, and companies with a target debt ratio. Also moderately important were the transaction costs and fees for issuing debt (rating 1.33). This factor was more important for large-sized companies, companies from the retail and wholesale business sector, firms with the legal form of a joint-stock company, and companies which have a target debt ratio. Statements of factors having a distinctly low impact were identified as follows: "To ensure that upper management works hard and efficiently, we issue sufficient debt to make sure that a large portion of our cash flow is committed to interest payments" (rating 0.36), "We try to have enough debt that we are not an attractive takeover target" (0.38), and "A high debt ratio helps us bargain for concessions from our employees" (0.46).

Table 3

Analysis of the Czech sample: Survey responses to the question: "What other factors affect your firm's debt policy?"

\begin{tabular}{|c|c|c|c|c|c|c|c|c|c|c|c|c|c|}
\hline & & \multicolumn{2}{|c|}{ Sample } & \multicolumn{2}{|c|}{ Size } & \multicolumn{3}{|c|}{ Business sector } & \multicolumn{3}{|c|}{ Legal form } & \multicolumn{2}{|c|}{$\begin{array}{l}\text { Target debt } \\
\text { ratio }\end{array}$} \\
\hline & & $\%$ & Mean & SME & Large & Manuf. & $\begin{array}{l}\text { Retail// } \\
\text { Wh. }\end{array}$ & Others & JSC & LLC & Others & Yes & No \\
\hline a) & $\begin{array}{l}\text { We issue debt when our recent profits } \\
\text { (internal funds) are not sufficient to } \\
\text { fund our activities }\end{array}$ & 59.30 & 2.54 & 2.51 & 2.65 & 2.86 & 2.39 & 2.37 & 2.61 & 2.73 & 1.84 & 2.73 & 2.59 \\
\hline b) & $\begin{array}{l}\text { Using debt gives investors a better } \\
\text { impression of our firm's prospects } \\
\text { than issuing stock }\end{array}$ & 4.22 & 0.35 & 0.34 & 0.38 & 0.21 & 0.41 & 0.42 & 0.55 & 0.33 & 0.17 & 0.73 & 0.27 \\
\hline c) & $\begin{array}{l}\text { We issue debt when interest rates are } \\
\text { particularly low }\end{array}$ & 13.86 & 0.99 & 0.92 & 1.24 & 0.87 & 1.33 & 0.83 & 1.24 & 1.06 & 0.43 & 1.50 & 0.89 \\
\hline d) & $\begin{array}{l}\text { We use debt when our equity is } \\
\text { undervalued by the market }\end{array}$ & 2.42 & 0.35 & 0.30 & 0.54 & 0.27 & 0.46 & 0.35 & 0.42 & 0.40 & 0.10 & 0.64 & 0.29 \\
\hline e) & $\begin{array}{l}\text { We delay issuing debt because of } \\
\text { transactions costs and fees }\end{array}$ & 10.84 & 0.90 & 0.89 & 0.86 & 0.72 & 1.20 & 0.85 & 1.05 & 0.92 & 0.65 & 1.50 & 0.76 \\
\hline f) & $\begin{array}{l}\text { We delay retiring debt because of } \\
\text { recapitalization costs and fees }\end{array}$ & 3.03 & 0.45 & 0.47 & 0.41 & 0.45 & 0.48 & 0.43 & 0.58 & 0.48 & 0.17 & 0.36 & 0.45 \\
\hline g) & $\begin{array}{l}\text { Changes in the price of our common } \\
\text { stock }\end{array}$ & 1.88 & 0.25 & 0.21 & 0.42 & 0.13 & 0.48 & 0.20 & 0.54 & 0.22 & 0.03 & 0.65 & 0.17 \\
\hline h) & $\begin{array}{l}\text { We issue debt when we have } \\
\text { accumulated substantial profits }\end{array}$ & 4.85 & 0.62 & 0.64 & \begin{tabular}{|l|}
0.57 \\
\end{tabular} & 0.75 & 0.81 & 0.36 & 0.71 & 0.69 & 0.24 & 1.05 & 0.56 \\
\hline
\end{tabular}

Note: $\%$ - is the percentage of scores 3 -important and 4 - very important. Mean is the average score for each question. Responses in Likert Scale 0 - 4. Size: SME-less than 250 employees, Large-more than 250 employees. Legal form: JSC-joint stock company, LLC-limited liability company, Others-other legal forms. Target debt ratio: Yes-answers: strict target ratio+somewhat tight target range, No-no target. Source: own investigation 
On the basis of the evaluation of average responses (the mean in Table 3), it can be stated that the influence of the other factors which affect the firm's debt policy was perceived by respondents as less important. This can be deduced from the fact that the majority of the factors were evaluated with a mean score of less than 1. For deciding debt policy, the most important factor was revealed by the statement, "We issue debt when our recent profits (internal funds) are not sufficient to fund our activities" (rating 2.54 in Table 3), which supports the conclusions of the pecking-order theory (firms do not target a specific debt ratio, but instead use external financing only when internal funds are insufficient). The distribution of answers to this question, according to company size, business sector and legal form, is balanced across all categories. The second most important other factor - "We issue debt when interest rates are particularly low" (rating 0.99) - was slightly more important for large-sized companies, from the retail and wholesale business sector, with the legal form of a JSC, and simultaneously having a target debt ratio. The next factor in order of importance was given by the statement: "We delay issuing debt because of transaction costs and fees", while the importance of the transaction costs and fees for issuing debt has already been confirmed by question e) in Table 2. The least popular debt policy factor found was: "Changes in the price of our common stock" (rating 0.25). This is obviously due to the structure of the sample, where the majority of respondents were not publicly listed companies.

\subsubsection{Factors affecting the appropriate amount of debt - Cross-country comparison}

Cross-country comparative studies can be very important for a better understanding of the financial decision-making process in different environments. Such techniques have not been employed in finance to a great extent so far, but these comparisons can have notable implications for empirical studies in finance and for new financial theory-building. This applies particularly to the Czech environment, where such empirical studies are still deficient.

The synoptical distribution of answers to the identical capital structure questions from the Duke Special Survey on Corporate Policy is presented in tables 4 and 5.

The relative rankings of most determinants of capital structure are strikingly similar between all groups (Table 5). All groups of respondents ranked "Financial flexibility" as the most important factor of their debt policy, followed either by "The volatility of earnings and cash flows" (US, UK, Netherlands, Brazil, CR) or "the firm's credit rating" (Europe, Germany, France). Although the relative rankings of the factor financial flexibility is almost identical in all samples, the mean ratings are significantly different (3.39 in Europe compared to 1.71 in the CR and 1.84 in France). These differences could be attributed to both demographic and country-specific differences. Anyway, financial flexibility was confirmed to be the most important factor that influences the amount of debt in all countries. From one point of view, this seems to be evidence in favour of the pecking-order model, since flexibility increases the opportunity to choose between different financing alternatives. A different point of view is that flexibility may be important for other reasons than the pecking order (Brounen, 2006). Volatility of earnings and cash flow is an important determinant, having a close relationship to bankruptcy costs. The more volatile and unstable the earnings are, the more probable is a firm's bankruptcy. This cannot be fully applicable to the Czech sample, where the rating of "earnings volatility" (1.36) is quite high, and the rating of "The potential costs of bankruptcy, near-bankruptcy, or financial distress" is much lower (0.66). 
Table 4

Cross-country comparison: Survey responses to the question: "What other factors affect your firm's debt policy?"

\begin{tabular}{|c|c|c|c|c|c|c|c|c|c|c|c|c|c|c|c|c|c|}
\hline & & & & & & \multicolumn{8}{|c|}{ Europe (Brounen et al. 2006) } & \multirow{2}{*}{\multicolumn{2}{|c|}{\begin{tabular}{c|} 
Brazil \\
(Benetti et al. \\
2007)
\end{tabular}}} & & \\
\hline & & \multicolumn{2}{|c|}{$\begin{array}{c}\text { U.S. } \\
\text { (G\&H 2001) }\end{array}$} & \multicolumn{2}{|c|}{$\begin{array}{c}\text { Europe } \\
\text { (B\&M 2004) }\end{array}$} & \multicolumn{2}{|c|}{ U.K. } & \multicolumn{2}{|c|}{ Netherlands } & \multicolumn{2}{|c|}{ Germany } & \multicolumn{2}{|c|}{ France } & & & \multicolumn{2}{|c|}{$\begin{array}{c}\text { Czech Rep } \\
\text { (2016) }\end{array}$} \\
\hline & & $\%$ & Mean & $\%$ & Mean & $\%$ & Mean & $\%$ & Mean & $\%$ & Mean & $\%$ & Mean & $\%$ & Mean & $\%$ & Mean \\
\hline a) & $\begin{array}{l}\text { We issue debt when our } \\
\text { recent profits (internal funds) } \\
\text { are not sufficient to fund our } \\
\text { activities }\end{array}$ & 46.78 & 2.13 & 24.14 & 1.56 & 25.42 & 1.44 & 34.69 & 1.69 & 54.31 & 2.30 & 23.53 & 1.24 & 45.60 & 2.06 & 59.30 & 2.54 \\
\hline b) & $\begin{array}{l}\text { Using debt gives investors a } \\
\text { better impression of our } \\
\text { firm's prospects than issuing } \\
\text { stock }\end{array}$ & 9.83 & 0.96 & 20.00 & 1.55 & 8.77 & 0.91 & 2.08 & 0.65 & 4.31 & 0.75 & 11.76 & 1.06 & 6.30 & 0.67 & 4.22 & 0.35 \\
\hline c) & $\begin{array}{l}\text { We issue debt when interest } \\
\text { rates are particularly low }\end{array}$ & 46.35 & 2.22 & 44.83 & 2.10 & 29.31 & 1.53 & 14.89 & 1.19 & 32.76 & 1.87 & 24.49 & 1.33 & 27.30 & 1.80 & 13.86 & 0.99 \\
\hline d) & $\begin{array}{l}\text { We use debt when our equity } \\
\text { is undervalued by the market }\end{array}$ & 30.79 & 1.56 & 43.68 & 2.08 & 16.07 & 1.02 & 6.38 & 0.62 & 6.31 & 0.45 & 8.16 & 0.80 & 3.20 & 0.57 & 2.42 & 0.35 \\
\hline e) & $\begin{array}{l}\text { We delay issuing debt because } \\
\text { of transactions costs and fees }\end{array}$ & 10.17 & 1.06 & 5.81 & 0.92 & 3.64 & 0.75 & 2.13 & 0.40 & 5.26 & 0.75 & 8.33 & 0.71 & 22.70 & 1.39 & 10.84 & 0.90 \\
\hline f) & $\begin{array}{l}\text { We delay retiring debt } \\
\text { because of recapitalization } \\
\text { costs and fees }\end{array}$ & 12.43 & 1.04 & n.a. & n.a. & 0.00 & 0.53 & 2.13 & 0.55 & 7.02 & 0.89 & 4.35 & 0.59 & 13.60 & 1.11 & 3.03 & 0.45 \\
\hline g) & $\begin{array}{l}\text { Changes in the price of our } \\
\text { common stock }\end{array}$ & 16.38 & 1.08 & 15.12 & 1.34 & 8.93 & 0.82 & 4.44 & 0.60 & 2.80 & 0.46 & 4.65 & 0.65 & 7.80 & 0.66 & 1.88 & 0.25 \\
\hline h) & $\begin{array}{l}\text { We issue debt when we have } \\
\text { accumulated substantial } \\
\text { profits }\end{array}$ & 1.14 & 0.53 & 1.18 & 0.72 & 3.57 & 0.55 & 2.22 & 0.49 & 5.45 & 0.62 & 4.65 & 0.58 & 9.40 & 0.66 & 4.85 & 0.62 \\
\hline
\end{tabular}

Note: $\%$ - is the percentage of scores 3 -important and 4 - very important. Mean is the average score for each question. Responses in Likert Scale $0-4$.

Source: Graham and Harvey (2001), Bancel and Mittoo (2004), Brounen et al. (2006), Benetti (2007), own elaboration

"The transaction costs and fees for issuing debt" proved to be important determinants of capital structure in all surveyed countries, with the highest score of 2.07 in Brazil. The moderate importance of this factor (with scores ranging between 1.26 for the Netherlands and 1.75 for the U.K.) was found by Brounen et al.; the US and Bancel and Mittoo's samples scores were higher (1.95 and 1.94, respectively). In the Czech Republic this rating was 1.33 , which puts this factor in third position, and therefore it can be considered as relatively important. These findings support the hypothesis of Fisher, Heinkel and Zechner (1989), who argue that transaction costs prevent firms from frequently rebalancing their capital structure.

Table 5 shows survey responses to the question "What factors affect how you choose the appropriate amount of debt for your firm?” in the US sample (Graham \& Harvey, 2001), 16 European countries (Bancel \& Mittoo, 2004), the UK, the Netherlands, Germany and France (Brounen et al., 2006), Brazil (Benetti et al., 2007) and the Czech Republic. 
Table 5

Cross-country comparison: Survey responses to the question: "What factors affect how you choose the appropriate amount of debt for your firm?"

\begin{tabular}{|c|c|c|c|c|c|c|c|c|c|c|c|c|c|c|c|c|c|}
\hline & & & & & & \multicolumn{8}{|c|}{ Europe (Brounen et al. 2006) } & \multirow{2}{*}{\multicolumn{2}{|c|}{$\begin{array}{l}\text { Brazil } \\
\text { (Benetti et } \\
\text { al. 2007) }\end{array}$}} & & \\
\hline & & \multicolumn{2}{|c|}{$\begin{array}{c}\text { U.S. } \\
\text { (G\&H 2001) }\end{array}$} & \multicolumn{2}{|c|}{$\mid \begin{array}{c}\text { Europe } \\
(\text { B\&M 2004) }\end{array}$} & \multicolumn{2}{|c|}{ U.K. } & \multicolumn{2}{|c|}{ Netherlands } & \multicolumn{2}{|c|}{ Germany } & \multicolumn{2}{|c|}{ France } & & & \multicolumn{2}{|c|}{$\begin{array}{c}\text { Czech Rep } \\
\text { (2016) }\end{array}$} \\
\hline & & $\%$ & Mean & $\%$ & Mean & $\%$ & Mean & $\%$ & Mean & $\%$ & Mean & $\%$ & Mean & $\%$ & Mean & $\%$ & Mean \\
\hline a) & $\begin{array}{l}\text { The tax advantage of interest } \\
\text { deductibility }\end{array}$ & 44.85 & 2.07 & 58.14 & 2.59 & 30.16 & 1.68 & 37.50 & 1.90 & 21.05 & 1.28 & 29.63 & 1.57 & 39.70 & 1.94 & 7.14 & 0.73 \\
\hline b) & $\begin{array}{l}\text { The potential costs of } \\
\text { bankruptcy, near-bankruptcy, } \\
\text { or financial distress }\end{array}$ & 21.35 & 1.24 & 30.95 & 1.76 & 30.16 & 1.37 & 27.08 & 1.42 & 7.08 & 0.65 & 24.07 & 1.22 & 32.30 & 1.45 & 8.43 & 0.66 \\
\hline c) & $\begin{array}{l}\text { The debt levels of other } \\
\text { firms in our industry }\end{array}$ & 23.40 & 1.49 & 23.26 & 1.84 & 16.13 & 1.11 & 26.53 & 1.37 & 14.04 & 1.14 & 12.96 & 1.24 & 23.10 & 1.35 & 10.78 & 0.77 \\
\hline d) & $\begin{array}{l}\text { Our credit rating (as assigned } \\
\text { by rating agencies) }\end{array}$ & 57.10 & 2.46 & 73.17 & 2.78 & 27.42 & 1.48 & 34.04 & 1.53 & 38.60 & 1.85 & 30.19 & 1.58 & 31.80 & 1.61 & 18.07 & 1.19 \\
\hline e) & $\begin{array}{l}\text { The transactions costs and } \\
\text { fees for issuing debt }\end{array}$ & 33.52 & 1.95 & 33.33 & \begin{tabular}{|l|}
1.94 \\
\end{tabular} & 25.40 & 1.68 & 15.22 & 1.26 & 26.32 & 1.50 & 21.15 & 1.42 & 47.10 & \begin{tabular}{|l|}
2.07 \\
\end{tabular} & 21.56 & 1.33 \\
\hline f) & $\begin{array}{l}\text { The personal tax cost our } \\
\text { investors face when they } \\
\text { receive interest income }\end{array}$ & 4.79 & 0.68 & 10.59 & 0.96 & 3.23 & 0.65 & 4.35 & 0.61 & 6.31 & 0.75 & 10.00 & 0.84 & 12.70 & 0.95 & 8.38 & 0.56 \\
\hline g) & $\begin{array}{l}\text { Financial flexibility (we } \\
\text { restrict debt so we have } \\
\text { enough internal funds } \\
\text { available to pursue new } \\
\text { projects when they come } \\
\text { along) }\end{array}$ & 59.38 & 2.59 & 90.80 & 3.39 & 50.00 & 2.13 & 51.06 & 2.32 & 47.83 & 2.17 & 37.25 & 1.84 & 47.70 & 2.22 & 33.53 & \begin{tabular}{|l|}
1.71 \\
\end{tabular} \\
\hline h) & $\begin{array}{l}\text { The volatility of our earnings } \\
\text { and cash flows }\end{array}$ & 48.08 & 2.32 & 32.56 & 1.97 & 35.48 & 1.73 & 42.55 & 2.06 & 30.97 & 1.67 & 34.78 & 1.54 & 49.20 & 2.20 & 23.81 & 1.36 \\
\hline i) & $\begin{array}{l}\text { We limit debt so our } \\
\text { customers/suppliers are not } \\
\text { worried about our firm going } \\
\text { out of business }\end{array}$ & 18.72 & 1.24 & 4.65 & 0.85 & 34.43 & 1.62 & 8.33 & 0.96 & 15.04 & 1.10 & 31.91 & 1.62 & 35.40 & 1.80 & 18.67 & 1.24 \\
\hline i) & $\begin{array}{l}\text { We try to have enough debt } \\
\text { that we are not an attractive } \\
\text { takeover target }\end{array}$ & 4.75 & 0.73 & 1.16 & 0.44 & \begin{tabular}{|l|}
0.00 \\
\end{tabular} & 0.58 & 2.13 & 0.38 & 2.68 & 0.48 & 6.52 & 0.61 & 20.00 & 1.14 & 3.57 & \begin{tabular}{|l|}
0.38 \\
\end{tabular} \\
\hline k) & $\begin{array}{l}\text { If we issue debt our } \\
\text { competitors know that we } \\
\text { are very unlikely to reduce } \\
\text { our output }\end{array}$ & 2.25 & 0.40 & 0.00 & 0.27 & 3.33 & 0.60 & 0.00 & 0.24 & 2.68 & 0.43 & 2.22 & 0.40 & 12.30 & 0.85 & 5.39 & \begin{tabular}{|l|}
0.55 \\
\end{tabular} \\
\hline 1) & $\begin{array}{l}\text { A high debt ratio helps us } \\
\text { bargain for concessions from } \\
\text { our employees }\end{array}$ & 0.00 & 0.16 & 6.98 & 0.73 & 0.00 & 0.27 & 0.00 & 0.24 & 0.92 & 0.30 & 0.00 & 0.41 & 7.70 & 0.52 & 4.19 & 0.46 \\
\hline m) & $\begin{array}{l}\text { To ensure that upper } \\
\text { management works hard and } \\
\text { efficiently, we issue sufficient } \\
\text { debt to make sure that a } \\
\text { large portion of our cash } \\
\text { flow is committed to interest } \\
\text { payments }\end{array}$ & 1.69 & 0.33 & 50.00 & 2.33 & 4.84 & 0.52 & 2.22 & 0.27 & 0.93 & 0.31 & 7.32 & 0.63 & 7.80 & 0.64 & 1.22 & 0.36 \\
\hline n) & $\begin{array}{l}\text { We restrict our borrowing so } \\
\text { that profits from new/future } \\
\text { projects can be captured fully } \\
\text { by shareholders and do not } \\
\text { have to be paid out as } \\
\text { interest to debtholders }\end{array}$ & 12.57 & 1.01 & n.a. & n.a. & 21.05 & 1.30 & 8.89 & 0.73 & 19.27 & 1.06 & 22.73 & \begin{tabular}{|l|}
1.27 \\
\end{tabular} & 28.80 & 1.42 & 3.64 & 1.44 \\
\hline
\end{tabular}

Note: \% - is the percentage of scores 3 - important and 4 - very important. Mean is the average score for each question. Responses in Likert Scale $0-4$.

Source: Graham and Harvey (2001), Bancel and Mittoo (2004), Brounen et al. (2006), Benetti (2007), own elaboration 
Some evidence that product market factors affect debt decisions was found in most countries. Responses to the statement, "We limit debt so our customers/suppliers are not worried about our firm going out of business" (Table 5), had a mean rating of between 0.85 in Europe (B\&M) and 1.8 in Brazil. Its rating value in the Czech Republic was 1.24 (exactly the same as in the US). The numbers confirm the proposition that debt should be limited so that a firm's customers or suppliers do not become concerned that the firm may go out of business (Graham and Harvey, 2001).

The "tax advantage of interest deductibility" and the "potential costs of bankruptcy or financial distress" are supposed to be the main determinants of capital structure, according to trade-off theory. The cross-country comparison of these two factors indicates that tax advantages are considered to be of quite high importance by U.S. and European companies (only in Germany is the importance lower); however, this finding is not applicable to the respondent firms from the Czech Republic (Table 5). Here the mean rating is extremely low (0.73), and only $7 \%$ of respondents evaluated this factor as important or very important. The Czech sample is also the only group where a larger share of respondents ( $8.43 \%$ ) evaluated bankruptcy costs as important or very important compared to tax advantages. In all other observed groups the firms consider bankruptcy costs to be of lesser importance than tax advantages $(\%$ and mean are lower or the same - Table 5).

Results of cross-country comparison show the modest concern of managers about the debt levels of their competitors. Ratings (Table 5) range between 1.84 for Europe (B\&M, 2004) and 1.11 for UK (Brounen, 2006). The result for the Czech Republic (0.77) is, surprisingly, far below American and European values. It either means that Czech companies have low interest in the debt levels of their competitors or, which is more probable, the availability of such data is lower in the Czech Republic.

The statement, "We restrict our borrowing so that profits from new/future projects can be captured fully by shareholders and do not have to be paid out as interest to debtholders" was rated as being to some extent important in most countries, with mean values from 0.73 in the Netherlands to 1.44 in the Czech Republic (Table 5). Even if the mean rating is quite high in the CR, the percentage of important and very important scores was very low (only $3.64 \%$ ). In all other countries the ratio of respondents considering this factor as important or very important is considerably higher (28.8\% in Brazil, $22.73 \%$ in France, $21.05 \%$ in the UK). This question has its basis in the underinvestment problem introduced by Myers (1977), which is an agency problem between bondholders and shareholders that arises in situations of debt predominance. In such cases, even if a firm has positive growth opportunities, new projects are not implemented to avoid situations where the bondholders benefit more than the shareholders.

In the majority of groups (the U.S., the U.K., Germany and Brazil), the same two factors were identified as having distinctly low impact, as given by the statements: "A high debt ratio helps us bargain for concessions from our employees" and "To ensure that upper management works hard and efficiently, we issue sufficient debt to make sure that a large portion of our cash flow is committed to interest payments". In the Netherlands and France, the factors with the lowest mean ratings are expressed by the statements " $\mathrm{A}$ high debt ratio helps us bargain for concessions from our employees" and "If we issue debt our competitors know that we are very unlikely to reduce our output". This confirms Graham's (2001) finding that debt policy is not used as bargaining device. In the Czech Republic and European sample there was one more factor with very low impact - expressed as, "We try to have enough debt that we are not an attractive takeover target" - besides the above-mentioned factors. This consideration is relatively unimportant in all national samples, where the average scores are below 0.73 . It is necessary to add to this finding that privately held companies normally are not a takeover target in comparison to publicly held companies.

To make the analysis more detailed and to detect certain country patterns in the examined relationships, the correlation analysis was also performed for individual countries (the data for Europe (B\&M 2004) were 
excluded because of missing values), as shown in Table 6. The strongest relationship in the responses to statements a) to n) for question "What factors affect how you choose the appropriate amount of debt for your firm?" was revealed between the data of the U. K. and France. It can be stated that the correlation of answers of the Czech respondents is positive and significant for all other countries; the strongest relation is with Germany and France (both European countries).

Table 6

The results of correlations: mean ratings of answers to the question: "What factors affect how you choose the appropriate amount of debt for your firm?”

\begin{tabular}{|c|c|c|c|c|c|c|c|}
\hline & US & UK & NL & DE & FR & BR & CZ \\
\hline US & 1 & & & & & & \\
\hline UK & 0,8995 & 1 & & & & & \\
\hline NL & 0,9160 & 0,8708 & 1 & & & & \\
\hline DE & 0,8705 & 0,8767 & 0,7937 & 1 & & & \\
\hline FR & 0,8981 & 0,9670 & 0,8508 & 0,8882 & 1 & 1 & \\
\hline BR & 0,8475 & 0,9196 & 0,7897 & 0,8027 & 0,8560 & 1 \\
\hline CZ & 0,6925 & 0,8529 & 0,6687 & 0,9226 & 0,8272 & 0,7915 & 1 \\
\hline
\end{tabular}

Note: Correlation is significant at the 0.05 level.

Source: Own elaboration on the basis of G\&H (2001), Brounen et al. (2006), Benetti et al. (2007) and own research.

Table 4 shows the cross-country comparison of survey responses to the question "What other factors affect your firm's debt policy?". It turned out that the two most important factors for all groups of respondents are expressed by: "We issue debt when our recent profits are not sufficient to fund our activities" and "We issue debt when interest rates are particularly low".

The statement, "We issue debt when our recent profits (internal funds) are not sufficient to fund our activities" is in accordance with the conclusions of the pecking-order theory. However, this confirmation is weak, as the ratings are not very high (from 1.24 in France to 2.30 in Germany). The Czech sample had the highest rating of all groups (2.54), so the validity of the pecking-order theory had the strongest confirmation here.

The least important other factors affecting a firm's debt policy are given by: "We issue debt when we have accumulated substantial profits" (the U.S., the E.U., the U.K., France), "Changes in the price of our common stock" (the Czech Republic), "We delay issuing debt because of transactions costs and fees" (the Netherlands), and "We use debt when our equity is undervalued by the market" (Brazil). All those factors' means were more or less under the value of 1 , so they should not be seen as critical for capital structure form.

If the ratings of the statement, "We issue debt when interest rates are particularly low" are compared with the ratings of the factor from Table 5, "The tax advantage of interest deductibility", the higher ratings remain in only 3 groups (the U.S., Germany, and the Czech Republic). This can be interpreted to mean that the tax advantages of interest deductibility are perceived as more important than the advantages of low interest rates by firms in most countries.

The statement, "We use debt when our equity is undervalued by the market" (Table 4) receives very low scores in most countries (below 1 in the Netherlands, Germany, France, Brazil, and the Czech Republic). On the other hand, the importance of debt issues when equity is undervalued is quite important in the U.S., where capital markets are more liquid and play a more important role in equity pricing and corporate 
financing. The European score from Bancel and Mittoo's survey is quite high as well, probably because the sample contained a majority of publicly listed companies. The same explanation can be used for the factor, "Changes in the price of our common stock", which has a rating above 1 only in the U.S. and European samples. Generally, this factor cannot be considered as crucial in capital structure determination.

Fisher, Heinkel and Zechner (1989) argue that transaction costs prevent firms from frequently rebalancing their capital structure. Responses to the questionnaires don't show strong support for this claim (see the statement, "We delay issuing debt because of transactions costs and fees" in Table 4). Transaction costs cannot be counted as a major determinant of corporate capital structure in the majority of countries. The ratings were mostly under 1, except in the U.S. (1.06) and Brazil (1.39).

Table 7

The results of correlations: mean ratings of answers to the question: "What other factors affect your firm's debt policy?"

\begin{tabular}{|c|c|c|c|c|c|c|c|}
\hline & US & UK & NL & DE & FR & BR & CR \\
\hline US & 1 & & & & & & \\
\hline UK & 0,7410 & 1 & & & & & \\
\hline NL & 0,6542 & 0,8142 & 1 & & & & \\
\hline DE & 0,6348 & 0,7190 & 0,9383 & 1 & & & \\
\hline FR & 0,2425 & 0,6487 & 0,5725 & 0,5427 & 1 & 1 & \\
\hline BR & 0,6840 & 0,6134 & 0,8544 & 0,9461 & 0,3684 & & \\
\hline CR & 0,5041 & 0,5647 & 0,8608 & 0,8755 & 0,3318 & 0,9316 & 1 \\
\hline
\end{tabular}

Note: Correlation is significant at the 0.05 level.

Source: Own elaboration on the basis of G\&H (2001), Brounen et al. (2006), Benetti et al. (2007) and own research.

Table 7 shows correlation coefficients of responses to statements a) to h) for question "What other factors affect your firm's debt policy?" depending on the particular country. The strongest relationship in the responses was revealed between the data of Germany and the Netherlands. It can be stated that the correlation of answers of the Czech respondents is positive and significant for all other countries, although the power of dependence is smaller than in the previous set of statements. In this case, the strongest relation of the Czech Republic is with Brazil, followed by Germany and the Netherlands.

\section{CONCLUSIONS}

The paper contributes to the literature by examining the practice of corporate finance in the Czech Republic, and by comparison with the results of previous studies performed in the United States (Graham and Harvey, 2001), 16 European countries (Bancel \& Mittoo, 2004), the United Kingdom, the Netherlands, Germany, and France (Brounen, de Jong, \& Koedijk, 2006), and Brazil (Benetti et al., 2007).

The study is based on empirical investigation in the Czech Republic, and the use of some of the questions from the questionnaire created by Graham and Harvey. The same questions were later used several times in various countries of America and Europe for cross-country comparison.

The trade-off theory of capital structure is based on a trade-off between the tax advantages and bankruptcy costs of debt. According to this theory, firms balance beneficial tax shields with financial distress costs when determining the appropriate amount of corporate debt. At the same time, those firms are expected to have a target debt ratio. From this point of view, it is possible to reject the validity of the tradeoff theory in the Czech environment, as the majority of respondent companies $(73.85 \%)$ have no target 
debt ratio. Similar results were found only by Brounen et al. (2006) only in France, where more than a half of the respondents had no target debt ratio. The results of further studies found moderate evidence for the static trade-off theory, as the majority of firms from the U.S., Europe and Brazil aim for some target debt ratio.

Financial flexibility proved to be the most important factor affecting the choice of the appropriate amount of debt for the Czech sample. This result is in accordance with the results of studies used for crosscountry comparison, in which all groups of respondents also ranked "Financial flexibility" as the most important factor of their debt policy. This finding can be seen as evidence in favour of the pecking-order theory.

The next significant factor for the Czech companies was the volatility of their earnings and cash flows. This factor was confirmed as very important even in all previous studies from the U.S., Europe, and Brazil (with ranking in the second or third position). The survey evidence for the importance of earnings volatility supports the trade-off theory of how optimal debt policy is chosen. Volatility of earnings and cash flow can have a close relationship to bankruptcy costs. The more volatile and unstable the earnings are, the more probable is a firm's bankruptcy. Brounen et al. (2006) found some evidence that European firms with high leverage were more concerned about bankruptcy costs as their expected bankruptcy costs were larger. This conclusion cannot be fully applied to the Czech sample, where the rating of "earnings volatility" is quite high, and the rating of "The potential costs of bankruptcy, near-bankruptcy, or financial distress" is much lower.

However, there are differences across countries in the ranking of the remaining factors affecting the appropriate amount of debt. "The transaction costs and fees for issuing debt" proved to be a more important determinant of capital structure in Brazil, the U.S., and Bancel and Mittoo's European sample. They were found to have moderate importance in Europe by Brounen et al., and by this investigation in the Czech Republic. Brounen doesn't consider transaction costs as a key driver of corporate debt policy. With respect to the relatively low scores of all factors in the Czech sample, this factor can be seen as important for Czech companies because it was rated in third position among all 14 factors.

The cross-country comparison of the "tax advantage of interest deductibility" factor indicates that tax advantages are considered to be of quite high importance to European and U.S. firms (the only exception is Germany). The great importance of this factor was also not confirmed in the Czech Republic. In all samples, including the Czech Republic, firms rated the importance of tax advantages of interest deductibility more highly than bankruptcy costs. The mean scores are quite high in most countries except the Czech Republic. Since bankruptcy costs are part of the static trade-off theory, volatility of earnings was considered to be more important in all countries.

The influence of the other factors which affect the firm's debt policy was perceived by Czech respondents as less important. Deciding on debt policy, the most important factor identified was expressed by the statement, "We issue debt when our recent profits (internal funds) are not sufficient to fund our activities“, which supports the conclusions of pecking-order theory. The cross-country comparison of the most important other factors that affect a firm's debt policy was surprisingly uniform because the two most important factors for all groups of respondents were given by the statements: "We issue debt when our recent profits (internal funds) are not sufficient to fund our activities" and "We issue debt when interest rates are particularly low".

The conclusions of this study reveal several interesting findings concerning the practice of capital structure choice in the Czech Republic and its cross-country comparison. A striking proportion of respondents in the Czech Republic have no target debt ratio; such a result was not found by any previous study. In the evaluation of the factors affecting the choice of the appropriate amount of debt and the firm's 
debt policy, no overwhelmingly notable variations between the Czech sample and the samples from the U.S., Europe and Brazil were found.

To make the analysis more detailed and to detect certain country patterns in the examined relationships, the correlation analysis was also performed for individual countries. The strongest correlation of the Czech responses was found out with Germany and France in both groups of statements, and with Brazil in the group of statements answering the question about other factors affecting firm's debt policy.

Although this research has reached its aims, there are some unavoidable limitations. First, considering the structure of the respondents, it is not possible to generalize the validity of the expressed conclusions and apply them to all businesses in the Czech Republic, but rather on non-publicly traded companies, with the legal form of limited liability company and the company size measured in sales revenues less than 25 million EUR, active in the manufacturing sector. Second, as pointed out even by the authors of previous studies (Bancel \& Mittoo, 2004), it is necessary to interpret the results of the questionnaire with some caution because of potential biases and measurement problems that are normally associated with survey data. Surveys measure beliefs and may not represent reality in the field.

This research is intended to be expanded by the use of all questions from the Duke Special Survey on Corporate Financial Policy for investigation in the Czech Republic (it is expected that some questions will have to be modified to suit the Czech context more).

\section{REFERENCES}

Archbold, S. \& Lazaridis, I. (2010). Capital structure decisions and decision making: survey evidence from the UK and Greece. In: Seventeenth Annual Conference of the Multinational Finance Society. Spain: Barcelona.

Bancel, F. \& Mittoo, U. R. (2004). Cross-Country Determinants of Capital Structure Choice: A Survey of European Firms. Financial Management, 33(4), 103-132.

Benetti, C. \& Decourt, R. \& Terra, P. (2007). The practice of corporate finance in Brazil and in the USA: comparative survey evidence. Anais: VII Encontro Brasileiro de Finanças. São Paulo.

Benetti, C. \& Decourt, R. \& Terra, P. (2007). The practice of corporate finance in an emerging market: preliminary evidence from the Brazilian survey. Annual Meeting of the Financial Management Association.

Brace, I. (2013). Questionnaire Design: How to Plan, Structure and Write Survey Material for Effective Market Research. Longon: Kogan Page.

Brealey, R. A. \& Myers, S. C. (1996). Principles of corporate finance. New York: McGraw-Hill.

Brounen, D. \& de Jong, A. \& Koedijk, K. (2004). Corporate Finance in Europe Confronting Theory with Practice. EFA 2004 Maastricht Meetings Paper No. 2769.

Brounen, D. \& de Jong, A. \& Koedijk, K. (2006). Capital structure policies in Europe: Survey evidence. Journal of Banking, 30(5), 1409-1442.

Fama, E. F. \& French, K. R. (2002). Testing trade-off and pecking order predictions about dividends and debt. The Review of Financial Studies, 15(1), 1-33.

Fischer, E.O. \& Heinkel, R. \& Zechner, J. (1989). Dynamic capital structure choice: theory and tests. Journal of Finance, $44,19-40$.

Graham, J. R. \& Harvey, C. R. (2001). The theory and practice of corporate finance: evidence from the field. Journal of Financial Economics, 60(2-3), 187-243.

Khan, M. Y. \& Jain, P. K. (2007). Basic Financial Management. New Delhi: Tata McGraw-Hill Education.

Kohli, A. \& Sharma, J. K. (2015). Survey of Corporate Financial Behavior of Indian MNCs. International Journal of Finance \& Accounting Studies, 3(1), 12-27.

Miller, M. H. \& Modigliani, F. (1958). The Cost of Capital, Corporation Finance, and the Theory of Investment. American Economic Review, 48(3), 261-297.

Myers, S.C. (1977). Determinants of corporate borrowing. Journal of Financial Economics, 5, 147-175. 
Myers, S. C. \& Majluf, N.S. (1984). Corporate financing and investment decisions when firms have information that investors do not have. Journal of Financial Economics, 13(2), 187-221.

Myers, S.C. (2003). Financing of Corporations. in Constantinides, G.M., Harris, M. and Stultz, R.M. (Eds). Handbook of Economics and Finance (Chapter 3), New York: Elsevier.

Shyam-Sunder, L. \& Myers, S. (1999). Testing static tradeoff against pecking order models of capital structure. Journal of Financial Economics, 51, 219-244. 